\title{
Detail Desain Embung Danau Kering Kota Padang
}

\author{
Syofyan.Z \\ Dosen Jurusan Teknik Sipil, Fakultas Teknik Sipil dan Perencanaan \\ Institut Teknologi Padang \\ DOI: http://dx.doi.org/10.31869/rtj.v3i2.1933
}

\begin{abstract}
Abstrak: Air dibutuhkan dalam kehidupan sedang ketersediaan air dari tahun ke tahun semakin berkurang sebaliknya kebutuhan akan air semakin meningkat setiap tahunnya. Kebutuhan air sebagai sumber air baku dan berbagai keperluan terutama untuk keperluan irigasi tetap perlu kiranya diambil langkah - langkah dalam usaha penyediaannya.

Dalam upaya penyediaan air baku ini, Pengembangan dan Pengelolaan Sumber Air Sumatera Barat memilih untuk membangun Embung sebagai penampung air. Untuk tujuan tersebut perlu dilakukan terlebih dahulu pembuatan Perencanaan Embung dalam hal ini membuat Detail Desain, dalam perencanaan Embug diperlukan analisa hidrologi yang terdiri dari analisa curah hujan rancangan, analisa kebutuhan Air di Daerah Studi, analisa debit banjir rancangan, kebutuhan daya tampung dan tinggi Embung dalam Detail Desain, dan analisa hidrolis konstruksi dan analisa stabilitas konsruksi agar bangunan aman terhadap kondisi yang berbahaya. Pengembangan dan Pengelolaan Sumber Air Sumatera Barat merealisasikan pembuatan perencanaan Embung (Detail Desain) pada Embung Danau Kering yang terletak di Desa Ulu Gadut kecamatan Pauh di Kot Padang.Dari hasil analisa diperoleh debit banjir rencana periode ulang 100 tahun sebesar 251.737 m3/dt, volume tampungan sebesar $894.770 \quad m 3$ berada pada elevasi $+105,00$ m yang digunakan sebagai elevasi mercu pelimpah, elevasi muka air banjir pada ketinggian $+106,78 \mathrm{~m}$, elevasi puncak bendungan pada ketinggian $+108,00 \mathrm{~m}$, elevasi dasar sungai pada ketinggian $+90.00 \mathrm{~m}$, tinggi jagaan diambil 2,00 $\mathrm{m}$, tinggi bendungan 18,00 m, lebar mercu bendungan 50,00 m,kemiringan lereng upstream 1:3,00, kemiringan lereng down stream 1:2,00. Tipe konstruksi bendungan Beton dengan Penyangga (concrete buttress dams)

Konstruksi stabil terhadap gaya-gaya yang terjadi pada kondisi yang berbahaya. volume genangan dan luas areal genangan $894.770 \mathrm{~m}^{3}$ dan $168.443,77 \mathrm{~m}^{2}$.
\end{abstract}

Kata kunci : analisa debit, kapasitas tampungan, konstruksi embung,

\section{PENDAHULUAN}

\section{Latar Belakang}

Kota Padang, ibukota propinsi Sumatra Barat merupakan Kota terbesar di propinsi ini, terletak pada $00^{\circ} 44^{\prime} 00^{\prime \prime}$ dengan $01^{\circ} 08^{\prime} 35^{\prime \prime}$ Lintang Selatan dan $100^{\circ}$ 05' $05^{\prime \prime}$ sampai dengan $100^{\circ} 34^{\prime} 09^{\prime \prime}$ Bujur Timur dengan luas $694.96 \mathrm{~km}^{2}$. Sebagai ibukota propinsi dan kota terbesar di Sumatera Barat, kegiatan perekonomian berpusat pula di kota ini, sudah barang tentu segala permasalahan juga tidak terlepas pada kota ini. Salah satu permasalahan serius yang dihadapi oleh kota Padang diantaranya adalah masalah banjir dan kebutuhan air baku yang merupakan masalah yang harus diantisipasi karena sangat terkait dengan perkembangan penduduk. Di sebelah timur dan sebelah selatan kota Padang terdapat pegunungan yang seharusnya berfungsi sebagai daerah konservasi dan daerah resapan hujan. Namun kondisi yang saat ini ada yang disebabkan oleh tingginya tingkat pembukaan lahan mengakibatkan daerah tersebut tidak dapat berfungsi menjadi daerah resapan lagi. Hal tersebut merupakan salah satu faktor utama penyebab banjir kota Padang. Di sisi lain, kebutuhan air baku dan kebutuhan air irigasi di kota Padang juga disuplai dari daerah aliran ini. Namun berkaitan dengan tidak berfungsinya daerah konservasi dan daerah resapan tersebut, hal ini menyebabkan ketersediaan air pada daerah tersebut mengalami penurunan yang cukup signifikan, sementara kebutuhan air untuk air baku khususnya di kota Padang terus mengalami peningkatan. Seiring berkembangnya penduduk di masa datang kebutuhan air untuk penduduk kota Padang dan sekitarnya akan meningkat tajam dari kebutuhan saat ini disamping kebutuhan untuk air irigasi dan keperluan lainnya. Bebagai alternatif terus dilakukan oleh instansi terkait setempat untuk mengantisipasi hal ini antara lain merencanakan untuk memanfaatkan Danau

\begin{tabular}{llr}
\hline ISSN 2599-2081 & Fakultas Teknik UMSB & 347
\end{tabular}

EISSN 2599-2090 
Kering yang berada disebelah timur kota Padang. Para praktisi dan ilmuan telah merekomendasikan agar pada lokasi Danau Kering ini dibangun embung untuk membendung sungai Batang Kuranji bagian hulu yang terletak di Desa Ulu Gadut kecamatan Pauh. Pembendungan akan dilakukan pada lembah yang agak sempit pada daerah aliran dengan luas lebih kurang 25 ha. Fungsi utama embung itu nantinya adalah untuk menstabilkan aliran baik dengan cara pengaturan persediaan air pada Danau Kering dan menyediakan simpanan (tampungan air) untuk pemanfaatan dikemudian hari, sekaligus untuk memperkecil dampak kerusakan akibat banjir dihilir embung. Untuk keperluan ini, instansi terkait telah melakukan segala persiapan antara lain pelaksanaan Studi Pendahuluan untuk melakukan kajian daerah aliran yang akan menjadi sasaran kegiatan ini, dilanjutkan dengan studi studi penunjang sehingga memperoleh rekomendasi kelayakan pembangunan Embung ini.

\section{Lokasi Pekerjaan}

Salah satu sungai besar yang berhulu di pegunungan di sebelah timur Kota Padang dan melintasi kota sebelum akhirnya bermuara ke samudera Indonesia adalah sungai Batang Kuranji. Sebagai salah satu sungai besar yang melintasi Kota Padang, sungai Batang Kuranji selain merupakan salah satu sumber air baku yang sangat dibutuhkan oleh penduduk, juga merupakan salah satu sungai yang seringkali menyebabkan banjir di Kota Padang dan sekitarnya.

Di bagian hulu sungai Batang Kuranji ini khususnya di Desa Ulu Gadut Kecamatan Pauh, terdapat Danau Kering yang seharusnya merupakan kawasan konservasi dan daerah resapan di bagian hulu sungai. Pembangunan embung dilakukan dengan membendung bagian hulu sungai Batang Kuranji.

Sarana dan Prasarana perhubungan menuju lokasi pekerjaan cukup sulit. Dari Kota Padang ke lokasi dapat dicapai dengan kendaraan roda empat sampai wilayah kelurahan Jawa Gadut Kecamatan Pauh, dan selanjutnya dilanjutkan dengan berjalan kaki melalui jalan setapak menyusuri sungai Limau Manis ke arah hulu sejauh kurang lebih $10 \mathrm{~km}$. Ilustrasi lokasi pekerjaan berdasarkan citra satelit tahun 2006 dapat dilihat pada Gambar 1.

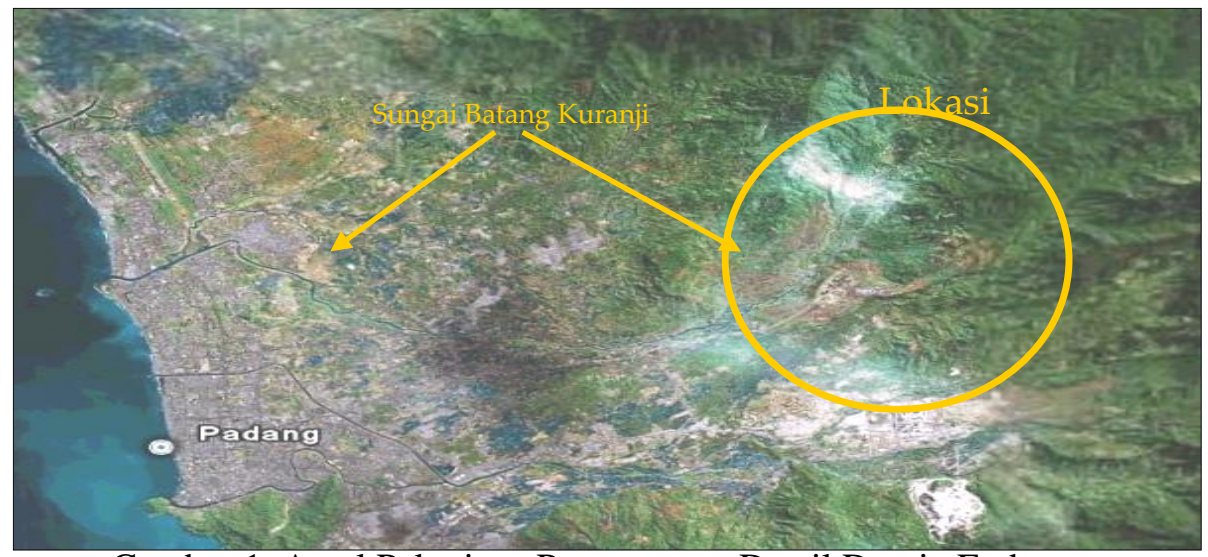

Gambar 1. Areal Pekerjaan Perencanaan Detail Desain Embung

\section{METODOLOGI}

\section{Tinjauan Umum}

Perencanaan embung diawali dengan melakukan survey dan investigasi di lokasi yang bersangkutan untuk memperoleh data perencanaan yang lengkap dan teliti. Metodologi yang baik dan benar merupakan acuan untuk menentukan langkah-langkah kegiatan yang perlu diambil dalam perencanaan (Soedibyo, 1993). Metodologi penyusunan perencanaan Embung sebagai berikut :

- Survey dan investigasi pendahuluan

- Identifikasi masalah

- Studi pustaka

- Pengumpulan data

- Analisis hidrologi

- Perencanaan konstruksi embung

- Stabilitas konstruksi embung

- Gambar Konstruksi 


\section{Metodologi Perencanaan Embung}

Metode perencanaan digunakan untuk menentukan langkah-langkah yang akan dilakukan dalam perencanaan Embung. Adapun metodologi perencanaan yang digunakan adalah :

- Survey dan investigasi pendahuluan dilakukan untuk mengetahui keadaan sosial, ekonomi, budaya masyarakat dan pengamatan lokasi di lapangan serta tanggapan masyarakat terhadap rencana pembangunan embung.

- Identifikasi Masalah Untuk dapat mengatasi permasalahan secara tepat maka pokok permasalahan harus diketahui terlebih dahulu. Solusi masalah yang akan dibuat harus mengacu pada permasalahan yang terjadi.

- Studi pustaka ini dilakukan untuk mendapatkan metode dalam analisis data, perhitungan dan perencanaan embung yang telah terbukti kebenarannya

- Pengumpulan data digunakan untuk mengetahui penyebab masalah dan untuk merencanakan embung yang akan dibuat. Data yang diperoleh berupa data primer dan sekunder.

- Analisis data yang telah didapat diolah dan dianalisis sesuai dengan kebutuhannya. Masing-masing data berbeda dalam pengolahan dan analisisnya. Pengolahan dan analisis yang sesuai akan diperoleh variabelvariabel yang akan digunakan dalam perencanaan embung.

- Perencanaan Konstruksi, Embung Hasil dari analisis data digunakan untuk menentukan perencanaan konstruksi embung yang sesuai, dan tepat disesuaikan dengan kondisikondisi lapangan yang mendukung konstruksi embung tersebut.

- Stabilitas Konstruksi Embung, Dalam perencanaan konstruksi embung perlu adanya pengecekan apakah konstruksi tersebut sudah aman dari pengaruh gaya-gaya luar maupun beban yang diakibatkan dari konstruksi itu sendiri (Sosrodarsono, 1989). Pengecekan stabilitas konstruksi pada tubuh bendungan merupakan usaha untuk dapat mengetahui keamanan konstruksi. Gaya-gaya yang bekerja dikontrol terhadap tiga penyebab runtuhnya bangunan gravitasi. Tiga penyebab runtuhnya bangunan gravitasi adalah gelincir, guling dan erosi bawah tanah (Soedibyo, 1993).

- Gambar Konstruksi, Hasil perencanaan dan stabilitas konstuksi embung diwujudkan dalam bentuk gambar yang detail dengan ukuran, bentuk dan skala yang ditentukan

- Bagan Alir, Keandalan hasil perencanaan erat kaitannya dengan alur kerja yang jelas, metoda analisis yang tepat dan kelengkapan data pendukung di dalam merencanakan embung. Adapun tahap- tahap analisis Perencanaan Embung adalah sebagai berikut :

\section{Bagan alir kegiatan}

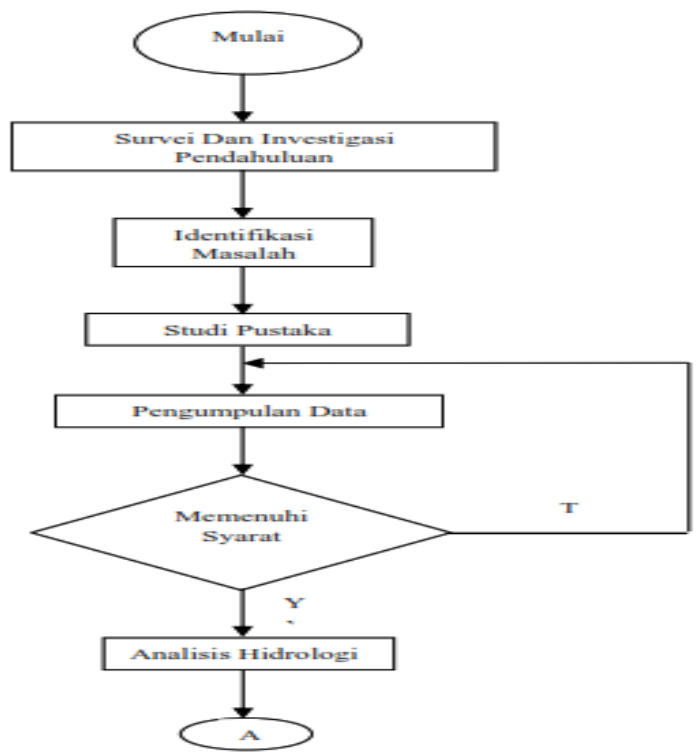




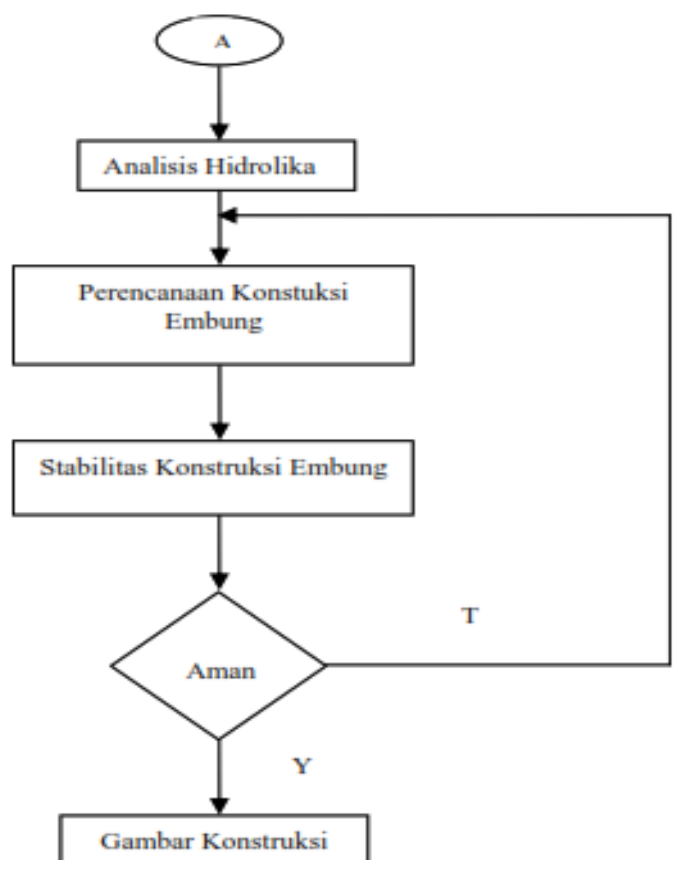

Gambar 2. Bagan alir kegiatan

\section{HASIL DAN PEMBAHASAN ANALISA HIDROLOGI \\ Kondisi Umum Lokasi Embung}

Lokasi perencanaan pembangunan Embung Danau Kering Kota Padang terletak disebelah timur laut Kota Padang. Data hidrologi dan meteorologi yang ada di kota Padang menunjukkan bahwa nilai evaporasi tahunan terhitung tinggi, kira-kira $1600 \mathrm{~mm}$ angka-angka tersebut lebih tinggi dibandingkan dengan evapotranspirasi tahunan di daerah pantai umumnya di Indonesia sebesar $1400 \mathrm{~mm}$. Musim hujan di lokasi perencanaan embung umumnya berlangsung selama lebih dari 6 bulan, mengingat secara umum distribusi bulan-bulan basah dan bulanbulan kering tidak begitu jelas dan kemungkinan kejadian hujan terjadi hampir di sepanjang tahun perkecualian bulan-bulan kering tertentu, dimana nilai curah hujan tahunan rata-rata hampir mencapai $4.000 \mathrm{~mm}$ yaitu sebesar $3.921,8 \mathrm{~mm}$ per-tahun. Kondisi ini tentunya sangat berbeda bila dibandingkan dengan kondisi di daerah lain seperti di Jawa, Bali, Nusa Tenggara dan sebagainya .

\section{Analisa Banjir Rencana}

Kejadian banjir dapat diramalkan besar dan kecepatan datang puncaknya setiap periode ulang, dan perlu dilakukan agar dapat diperkirakan dampaknya terhadap dearah disekitarnya. Idealnya perencanaan banjir rencana dilakukan kombinasi antara metode analisis frekuensi berdasarkan data hasil pencatatan debit banjir untuk periode panjang tertentu dengan analisis hidrologis berdasarkan data pencatatan curah hujan baik menggunakan rumus empiris maupun beberapa metode penurunan curah hujan debit banjir berupa hidrograf dan hidrograf satuan.

Untuk di lokasi yang berada di daerah hulu maupun di sekitar lokasi rencana penempatan Embung Danau Kering sama sekali tidak terdapat stasiun pencacatan hujan maupun pengukuran debit. Hal tersebut dikarenakan lokasi masih merupakan daerah hutan asli dan secara topografi berada pada daerah pegunungan yang masih belum terbuka ataupun tereksploitasi, sehingga tidak memungkinkan adanya stasiun hidroklimatologi maupun hidrometri sungai. Berdasarkan kondisi tersebut maka perencanaan analisa hidrologi baik yang meliputi analisa debit andalan maupun perencanaan banjir rencana hanya bisa dilakukan dengan melakukan pengolahan berdasarkan data hasil pencacatan curah hujan dari stasiun hujan terdekat yang dianggap paling mewakili / kondisinya paling mirip dengan lokasi perencanaan embung. Stasiun hujan yang memungkinkan untuk dipakai datanya adalah stasiun hujan Ladang Padi di Lubuk Kilangan. Stasiun Hujan Ladang Padi di Lubuk Kilangan berada pada lokasi yang terdekat dengan lokasi cathment area rencana lokasi Embung Danau Kering. Selain itu baik secara topografis maupun ketinggian diatas permukaan laut juga mendekati ketinggian yang sama, meskipun tidak berada pada satuan wilayah sungai yang sama dengan lokasi embung yang berada di sebelah hulu dari daerah aliran sungai (DAS) Batang Kuranji dan Sungai Limau Manis sementara stasiun Lubuk Kilangan berada pada daerah aliran sungai (DAS) Batang Arau.

Daerah tangkapan hujan pada lokasi rencana Embung Danau Kering mempunyai data-data sebagai berikut :

Catchment area $\quad=18.987 \mathrm{~km}^{2}$.

Panjang sungai utama $=5.247 \mathrm{~km}$.

Perkiraan debit banjir untuk kala ulang tertentu di daerah tangkapan hujan di hulu 
lokasi Embung Danau Kering dengan luas DAS yang relatif kecil dihitung dengan menggunakan pendekatan Metoda Unit Hidrograf Nakayasu dan Metode Unit Hidrograf Sintetik Gama I.

Dalam perhitungan kemungkinan banjir dilakukan berdasarkan pada distribusi hujan efektif tiap jam dan hulu lokasi pelimpah Embung Danau Kering diambil durasi 24 jam.

$$
R_{t}=R \cdot\left(\frac{24}{T}\right)^{\frac{2}{3}} \quad R=\frac{R_{24}}{24}
$$

dimana :

Rt $=$ rata-rata hujan dari awal sampai jam ke-T

$\mathrm{T}=$ waktu hujan awal sampai jam ke $-\mathrm{T}$

Besarnya curah hujan ke-T dihitung dengan menggunakan rumus :

$\mathrm{Rt}=\mathrm{t} \cdot \mathrm{Rt}-(\mathrm{t}-1) \cdot \mathrm{R}(\mathrm{t}-1)$

Dimana ;

$$
\mathrm{Rt}=\quad \text { curah hujan ke-T }
$$

RT = rata-rata hujan dari awal sampai jam ke-T

$\mathrm{t}=$ waktu hujan awak sampai jam ke-T

Selanjutnya membuat flood pattern metoda DR.Nakayasu seperti langkah berikut :

Perhitungan besar Q maks. Dengan persamaan

$$
Q_{\text {maks }}=\frac{1}{3.6} \cdot A \cdot \frac{R_{0}}{T_{p}+T_{0.3}}
$$

dengan bentuk kurva (hydrograph) sebagai berikut :

keadaan naik dengan $0<\mathrm{t}<\mathrm{Tp}$

$Q=\left(\frac{t}{T}\right)^{2.4} \cdot Q_{\text {maks }}$

keadaan kurva menurun dengan $\mathrm{Tp}<\mathrm{t},(\mathrm{Tp}+$ $\mathrm{T} 0.3)$

$$
Q=0.3^{\left(\frac{1-T_{p}}{T_{0.3}}\right)} \cdot Q_{\text {maks }}
$$

keadaan $(\mathrm{Tp}+\mathrm{T} 0.3)<\mathrm{t}<(\mathrm{Tp}+\mathrm{T} 0.3+1.5$ $\mathrm{Tp})$

$$
Q=0.3^{\left(\frac{1-T_{p}+0.5 T_{0.3}}{1.5 T_{0.3}}\right)} \cdot Q_{\text {maks }}
$$

keadaan $\mathrm{t}>(\mathrm{Tp}+\mathrm{T} 0.3+1.5 \mathrm{Tp})$

$$
Q=0.3^{\left(\frac{1-T_{p}+0.5 T_{0.3}}{2 . T_{0.3}}\right)} \cdot Q_{\text {maks }}
$$

Dimana :

Q maks $\quad=\quad \mathrm{Q}$ puncak pada kurva (grafik) dalam m3/det

$\mathrm{R}=$ Curah hujan efektif (mm)

$\mathrm{A}=$ Luas daerah pengaliran $(\mathrm{km} 2)$

$\mathrm{T}_{\mathrm{p}}=$ Waktu naik (jam)

$\mathrm{T}_{0.3}=$ Waktu menurun dari puncak (peak) ke 0.3 Qmaks (jam)

Dengan ketentuan :

$\mathrm{T}_{\mathrm{p}}=\mathrm{T}_{\mathrm{g}}+0.8 \mathrm{~T}_{\mathrm{r}}$

$\mathrm{T}_{0.3}=\alpha$. $\operatorname{Tg}(\alpha=$ koefisien antara 1,5-3,5 $)$

$0.4+0.058 . \mathrm{L}$

$$
\text { Untuk } \mathrm{L}<15 \mathrm{Km} \quad \mathrm{Tg}=
$$

$=0.21 . \mathrm{L} 0.7$

$$
\mathrm{L}>15 \mathrm{Km} \quad \mathrm{Tg}
$$

Dimana :

$\mathrm{T}_{\mathrm{g}}=$ Log time pada daerah aliran (jam)

$\mathrm{T}_{\mathrm{r}}=$ Unit Time of Rain Fall ( jam )

$\mathrm{L}=$ panjang sungai $(\mathrm{km})$

Luas DAS dan panjang sungai dari hulu sungai terjauh ke titik pengukuran akan menentukan besarnya debit puncak yang terjadi dan waktu tunda banjir maksimum setiap DAS, dengan demikian masing-masing sungai mempunyai Hidrograf satuan berbeda seperti Daerah Tangkapan Hujan Danau Kering.

Hidrograf Satuan yang terbentuk mempresentasikan jumlah debit dari waktu ke waktu di titik pengukuran yang timbul akibat hujan yang dianggap jatuh secara merata seluruh DAS setinggi $1 \mathrm{~mm}$. Dengan pola grafik yang sama debit banjir rencana setiap periode ulang dapat dibuat atas dasar curah hujan rencana setiap jam.

Hasil perhitungan debit rencana diberikan dalam bentuk grafis pada Grafik 1 berikut. 


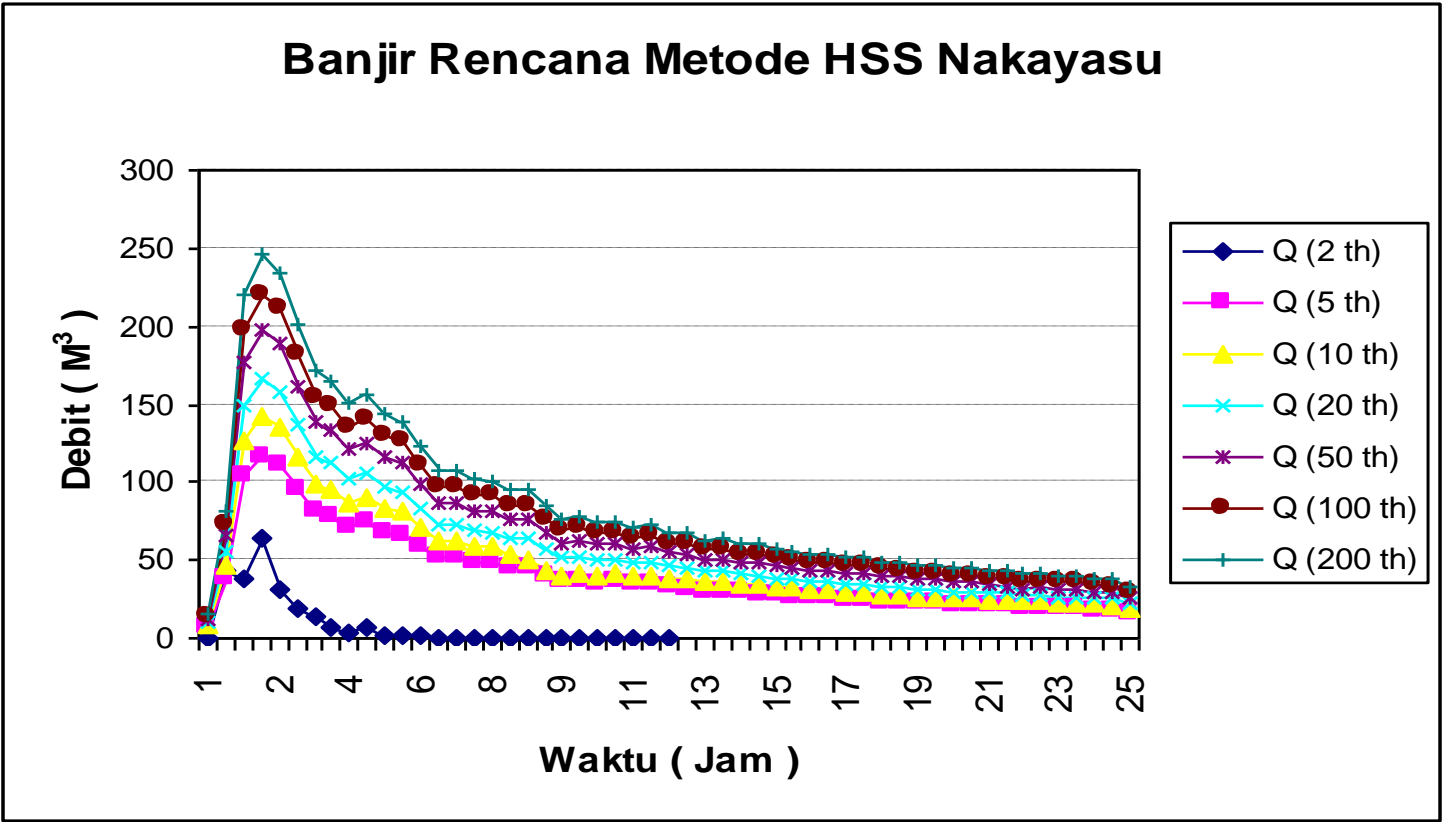

Grafik 1. Hasil Perhitungan Banjir Rencana Mengggunakan Metode HSS Nakayasu Selanjutnya perhitungan banjir rencana juga

Dimana sebagaimana ditunjukkan pada tabel dan grafik di atas, debit puncak terjadi pada saat jam ke 1,52 dengan debit banjir rencana 100 tahunan sebesar $220,597 \mathrm{~m}^{3} /$ detik. dilakukan dengan metode Hidrograf Satuan Sintetik HSS Gama I. Hasil perhitungan debit rencana diberikan dalam bentuk grafis pada Grafik 2 berikut.

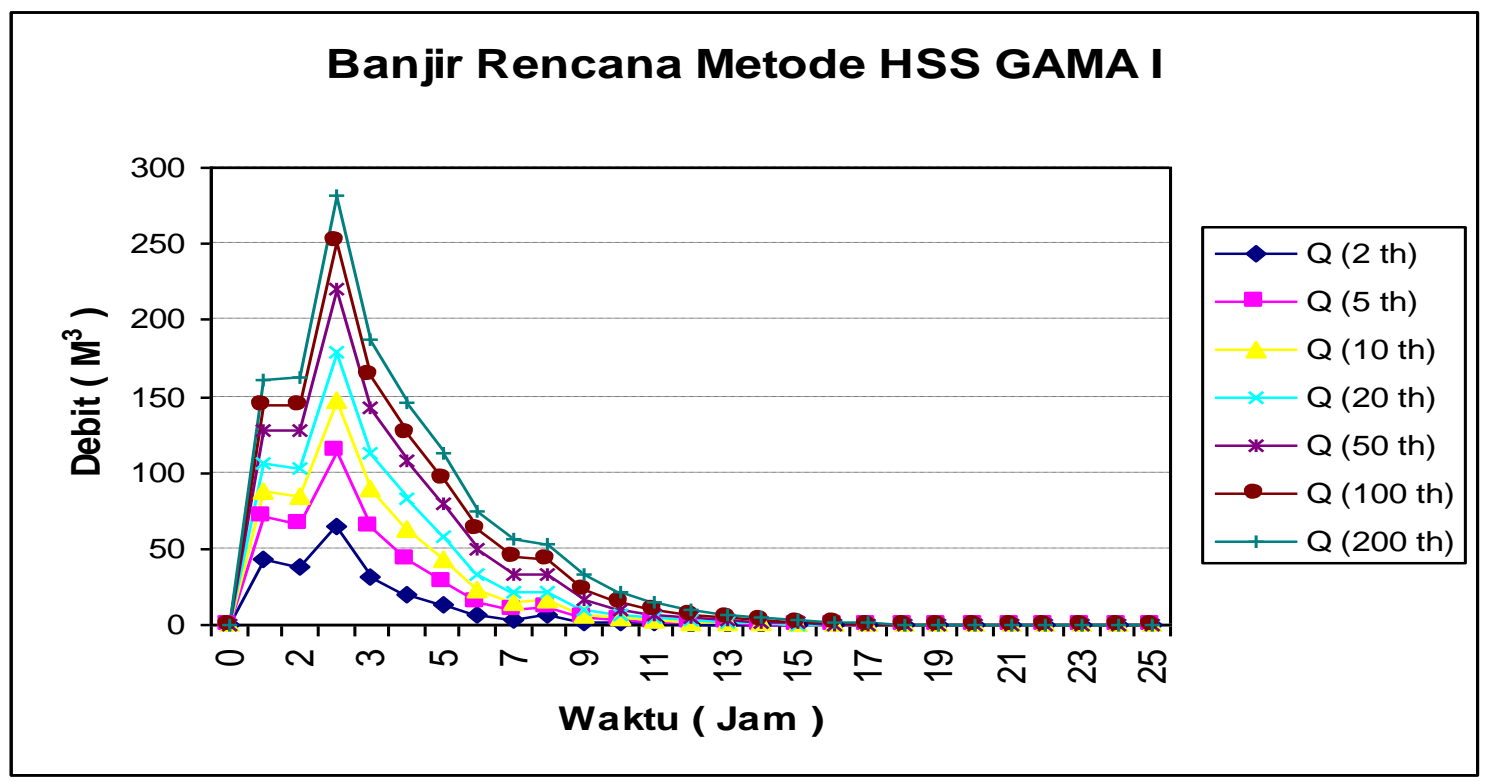

Grafik 2. Hasil Perhitungan Banjir Rencana Mengggunakan Metode HSS Gama I.

Dimana sebagaimana ditunjukkan pada tabel diatas, debit puncak terjadi pada saat jam ke 2,2 dengan debit banjir rencana 100 tahunan sebesar $251,737 \mathrm{~m}^{3} /$ detik.

Selanjutnya berikut diberikan rekapitulasi perbandingan hasil perhitungan debit banjir rencana dengan menggunakan kedua metode perhitungan di atas yaitu Metode HSS Nakayasu dan HSS Gama I. 
Tabel 1. Rekapitulasi Perhitungan Banjir

Rencana Metode HSS Nakayasu dan Metode HSS Gama I

\begin{tabular}{|c|c|c|}
\hline $\begin{array}{c}\text { Periode } \\
\text { Ulang }\end{array}$ & HSS NAKAYASU & HSS GAMA I \\
\hline $\mathrm{Q}_{2}$ & 78.205 & 64.375 \\
\hline $\mathrm{Q}_{5}$ & 116.327 & 114.536 \\
\hline $\mathrm{Q}_{10}$ & 141.567 & 147.747 \\
\hline $\mathrm{Q}_{20}$ & 165.777 & 179.603 \\
\hline $\mathrm{Q}_{50}$ & 197.114 & 220.838 \\
\hline $\mathrm{Q}_{100}$ & 220.597 & 251.737 \\
\hline $\mathrm{Q}_{200}$ & 245.445 & 282.525 \\
\hline
\end{tabular}

\section{Volume Embung}

Penetapan lokasi embung didasarkan pada beberapa pertimbangan diantaranya :

a. kondisi topografi

b. kondisi geologi dan mekanika tanah

c. kondisi hidrologis

dari petimbangan di dalam penetapan

lokasi bangunan Embung Danau Kering. Sedangkan tinggi mercu atau kedalaman maksimum genangan direncanakan setinggi 15 $m$ yang akan memberikan volume genangan dan luas areal genangan berturut-turut 894.770 $\mathrm{m}^{3}$ dan $168.443,77 \mathrm{~m}^{2}$. Rekapitulasi volume tampungan, luas genangan dan elevasi rencana mercu adalah sebagaimana diberikan pada Tabel 2. berikut.

Tabel 2. Rekapitulasi Hubungan Antara Elevasi, Luas Genangan dan Volume Genangan Rencana Embung Danau Kering.

\begin{tabular}{|c|c|c|}
\hline $\begin{array}{c}\text { Elevasi } \\
(\mathrm{m})\end{array}$ & $\begin{array}{c}\text { Luas Genangan } \\
\left(\mathrm{m}^{2}\right)\end{array}$ & $\begin{array}{c}\text { Volume Genangan } \\
\left(\mathrm{m}^{3}\right)\end{array}$ \\
\hline 0.00 & 0.00 & 0.00 \\
\hline 5.00 & $20,368.01$ & $18,164.00$ \\
\hline 10.00 & $77,768.98$ & $267,067.25$ \\
\hline 11.00 & $91,720.03$ & $367,477.00$ \\
\hline 12.00 & $124,339.15$ & $478,250.50$ \\
\hline 13.00 & $137,550.79$ & $603,221.25$ \\
\hline 14.00 & $157,798.18$ & $760,974.75$ \\
\hline 15.00 & $168,443.77$ & $894,770.00$ \\
\hline
\end{tabular}

\section{Perhitungan Hidrolis Mercu}

Perencanaan Hidraulis Mercu Embung

dilakukan berdasarkan buku Standar Perencanaan Irigasi Departemen PU (Th
1986), Standar Nasional Indonesia SNI 033432-1994 tentang Tata Cara Penetapan Banjir Disain Dan Kapasitas Pelimpahan Untuk Bendungan. Mercu Embung direncanakan sebagai mercu beton dengan bentuk mercu bulat. Kemiringan hilir $1: 1$ dengan jari-jari mercu pertama-tama diperkirakan 1.50 meter.

\section{Tinggi Mercu (Elevasi Spillway) Embung}

Perencanaan Spill way ini direncanakan berdasarkan volume tampungan perlu dan elevasi genangan yang direncanakan dengan :

Tinggi Mercu $(\mathrm{P})=15$ meter

\section{Lebar Efektif Spillway}

- Lebar pelimpah (spillway) diusahakan sama atau mendekati lebar sungai utama di sebelah hilir mercu yang ada atau sesuai ketersediaan lebar area pelimpahan, misal dalam contoh ini diberikan salah satu alternatif yang digunakan yaitu $\mathrm{L}=50.00$ meter.

$$
\begin{aligned}
\mathrm{Le} & =\mathrm{L}-\mathrm{T}-2(\mathrm{n} . \mathrm{Kp}+\mathrm{Ka}) * \mathrm{He} \\
\mathrm{L} & =50 \mathrm{~m} \\
\mathrm{n} & =3 \mathrm{bh} \\
\mathrm{Kp} & =0.01 \\
\mathrm{Ka} & =0.1
\end{aligned}
$$

Dimana :

$$
\begin{array}{ll}
\mathrm{Le} & =\text { Lebar Efektif Spillway } \\
\mathrm{L} & =\text { Lebar total spiilway } \\
\mathrm{n} & =\text { Jumlah pilar } \\
\mathrm{Kp} & =\text { Koefesien Kontraksi pilar } \\
\mathrm{Ka} & =\text { Koefesien Kontraksi Pangkal } \\
\text { Spillway }
\end{array}
$$

\section{Tinggi Air Di Atas Mercu Bendung}

Tinggi muka air di atas mercu dihitung berdasarkan rumus mercu bulat (Kp. 02 hal 4.2)

$$
Q=C_{d} \times 2 / 3 b_{e} \times \sqrt{2 / 3 g} \times H_{1}^{3 / 2}
$$

Dengan: $\mathrm{Q}=$ debit rencana $\left(\mathrm{Q}_{100}=\right.$ $251.737 \mathrm{~m}^{3} / \mathrm{dt}$ )

$\mathrm{C}_{1} \times \mathrm{C}_{2}$

$$
\mathrm{C}_{\mathrm{d}}=\text { koefisien debit }=\mathrm{C}_{0} \mathrm{x}
$$

$=45.50 \mathrm{~m})$

$b_{\text {eff }}=$ lebar efektif pelimpah $\left(b_{e}\right.$

$$
\mathrm{H}_{1}=\text { tinggi energi hulu }
$$

Harga-harga koefisien $\mathrm{C}_{0}, \mathrm{C}_{1}$ dan $\mathrm{C}_{2}$ dapat ditentukan dari Grafik KP - 02

Beff $\quad=\mathrm{L}-\left(\sum \mathrm{T}\right)$ 
Tabel 3. Perhitungan Koefisien Debit

\begin{tabular}{|c|r|r|r|r|r|l|}
\hline $\mathrm{He}(\mathrm{m})$ & \multicolumn{1}{|c|}{0.5} & \multicolumn{1}{|c|}{1} & \multicolumn{1}{c|}{1.5} & \multicolumn{1}{c|}{2} & \multicolumn{1}{c|}{2.5} & 3 \\
\hline $\mathrm{He} / \mathrm{R}$ & 0.33 & 0.67 & 1.00 & 1.33 & 1.67 & 2.00 \\
\hline $\mathrm{P} / \mathrm{He}$ & 30.00 & 15.00 & 10.00 & 7.50 & 6.00 & 5.00 \\
\hline $\mathrm{Co}$ & 0.92 & 1.10 & 1.18 & 1.23 & 1.26 & 1.32 \\
\hline $\mathrm{C} 1$ & 1.00 & 1.00 & 1.00 & 1.00 & 1.00 & 1.00 \\
\hline $\mathrm{C} 2$ & 1.00 & 1.00 & 1.00 & 1.00 & 1.00 & 1.00 \\
\hline $\mathrm{Cd}$ & 0.92 & 1.10 & 1.18 & 1.23 & 1.26 & 1.32 \\
\hline
\end{tabular}

$\mathrm{H}_{1}=2.0$ meter

$\mathrm{H} 1 / \mathrm{r}=2 / 1.5=1.33$

$\mathrm{P} / \mathrm{H1}=15 / 2=7.5$

$\frac{H_{1}}{r}=1.33$, maka $\mathrm{C}_{\mathrm{o}}=1.23$

$\frac{P}{H_{1}}=7.5$, maka $\mathrm{C}_{1} \quad=1$

$Q=C_{d} \times 2 / 3 b_{e} \times \sqrt{2 / 3 g} \times H_{1}^{3 / 2}$

$\frac{P}{H_{1}}=7.5$, maka $\mathrm{C}_{2} \quad=1$

Jadi $\mathrm{C}_{\mathrm{d}}=1.23 \times 1 \times 1$

$$
=1.23
$$

Setelah Cd di dapat, kita dapat menghitung Debit dengan rumus persamaan (1) diatas $\mathrm{Q} \quad=1.23 \times 2 / 340.5 \times \sqrt{ } 2.9 .8 \times 2^{3 / 2}$ $=269.735 \mathrm{M}^{3} / \mathrm{sec}$

Kemudian kita akan mendapatkan nilai $\mathrm{Hd}$ yang kita inginkan dengan cara coba - coba, dimana nilai He kita variasikan. Sehingga untuk debit sebesar banjir rencana $\mathrm{Q}_{100 \mathrm{th}}=$ $251.737 \mathrm{~m}^{3} / \mathrm{sec}$, kita mendapatkan $\mathrm{Hd}=1.78$ $\mathrm{m}$. Secara grafis muka air banjir rencana tersebut adalah sebagaimana diberikan pada Grafik 3.3. berikut.

Grafik 3. Tinggi Muka Air Banjir Rencana di atas Mercu Untuk Panjang Mercu Rencana L $=50 \mathrm{~m}$.

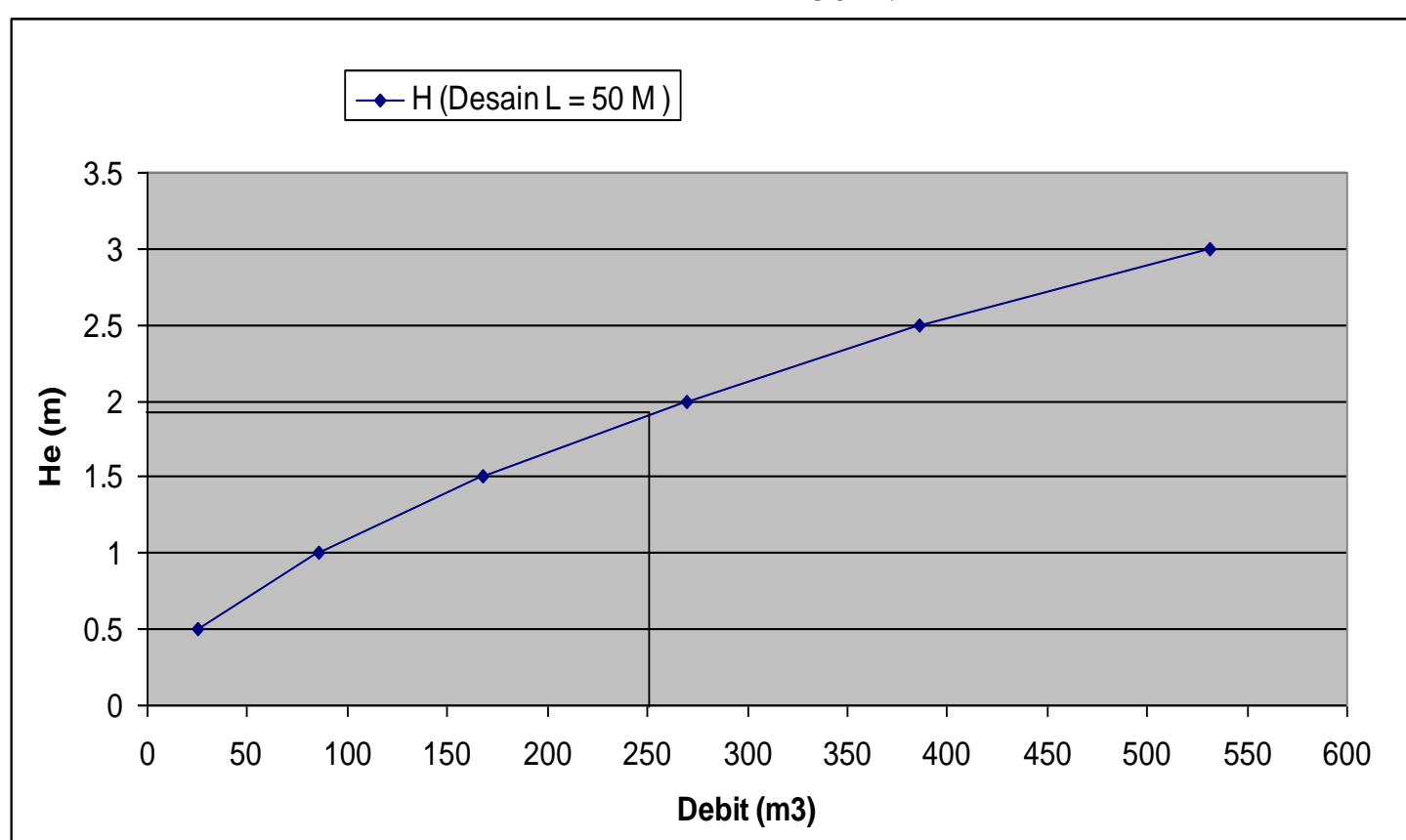

Untuk mengetahui efektifitas dan perbandingan alternatif dimensi mercu dan elevasi muka air banjir rencana diatas mercu, berdasarkan SNI 03 - 3432 - 1994 maka setidaknya mercu dapat direncanakan berdasarkan dua kondisi ektrim sebagai berikut.

Alternatif kondisi perencanaan 1:
Spillway bisa direncanakan dengan berdasarkan debit rencana sebesar $\mathrm{Q}_{\mathrm{R}}=0,5 \mathrm{x}$ $125 \% \mathrm{Q}_{100 t h}$, apabila bendungan mempunyai resiko kecil.

Alternatif kondisi perencanaan 2:

Spillway harus direncanakan dengan berdasarkan debit rencana sebesar $\mathrm{Q}_{\mathrm{R}}=125 \%$ $\mathrm{Q}_{100 \mathrm{th}}$, apabila bendungan mempunyai resiko besar. 
Dalam laporan ini dilakukan beberapa alternatif perhitungan disain spillway berdasarkan beberapa alternatif dimensi, elevasi muka air banjir dan besaran debit banjir rencana menggunakan prosedur yang

Tabel 4. Rekapitulasi Alternatif Dimensi Spillway Berdasarkan Debit Banjir Rencana, Tingkat Keamanan dan Elevasi Muka Air Banjir di Atas Mercu.

\begin{tabular}{|c|c|c|c|c|c|c|}
\hline \multirow[b]{2}{*}{$\begin{array}{l}\text { Lebar } \\
\text { Spillway }\end{array}$} & \multicolumn{2}{|c|}{$125 \% \times Q_{100}$} & \multicolumn{2}{|c|}{$125 \% \times 0,5 Q_{100}$} & \multicolumn{2}{|r|}{$Q_{100}$} \\
\hline & $\begin{array}{c}Q_{\mathrm{R}} \\
\left(\mathbf{m}^{3} /{ }_{\text {Det }}\right)\end{array}$ & $\begin{array}{c}\text { Tinggi Air } \\
\text { di Atas Mercu } \\
(\mathrm{m})\end{array}$ & $\begin{array}{c}Q_{R} \\
\left(m^{3} /_{\text {Det }}\right)\end{array}$ & $\begin{array}{c}\text { Tinggi Air } \\
\text { di Atas Mercu } \\
(\mathrm{m})\end{array}$ & $\begin{array}{c}\mathbf{Q}_{\mathrm{R}} \\
\left(\mathrm{m}^{3} /_{\text {Det }}\right)\end{array}$ & $\begin{array}{c}\text { Tinggi Air } \\
\text { di Atas Mercu } \\
(\mathrm{m})\end{array}$ \\
\hline 25 & 314.671 & 3.55 & 157.336 & 2.25 & 251.737 & 3.2 \\
\hline 30 & 314.671 & 3.08 & 157.336 & 2 & 251.737 & 2.8 \\
\hline 35 & 314.671 & 2.8 & 157.336 & 1.78 & 251.737 & 2.4 \\
\hline 40 & 314.671 & 2.2 & 157.336 & 1.6 & 251.737 & 2.3 \\
\hline 50 & 314.671 & 2.2 & 157.336 & 1.5 & 251.737 & 1.78 \\
\hline
\end{tabular}

\section{Analisa Keamanan Terhadap Rembesan} dan Erosi Bawah Tanah (Bahaya Piping)

\section{Kontrol Keamanan Terhadap Rembesan}

Kontrol keamanan terhadap rembesan di bawah tubuh bendung digunakan methode Lane, yaitu :

$$
\begin{aligned}
\Delta \mathrm{H} & =15 \mathrm{~m} \\
\mathrm{~L}_{\mathrm{w}} & =\mathrm{L}_{\mathrm{v}}+1 / 3 \mathrm{~L}_{\mathrm{h}}>\mathrm{C}_{\mathrm{w}} \cdot \Delta \mathrm{H}
\end{aligned}
$$

Harga $\mathrm{C}_{\mathrm{w}}$ untuk tanah pasir kasar adalah 2.5

Pada tabel 4.3, panjang $\mathrm{L}_{\mathrm{w}}$ pada titik $\mathrm{N}$ adalah 42.4

$$
\begin{aligned}
\mathrm{L}_{\mathrm{w}} & =42.4>2.5 \times 15 \\
& =42.4>37.5
\end{aligned}
$$

\section{Kontrol Keamanan Terhadap Erosi Bawah Tanah (Piping)}

Keamanan terhadap erosi bawah tanah (piping) adalah :

$$
S_{f}=\frac{S\left(1+\frac{a}{s}\right)}{H_{s}}
$$

Dengan : $\quad S_{\mathrm{f}}=$ faktor keamanan

$$
\begin{aligned}
& \mathrm{S}=\text { kedalaman tanah = } \\
& \mathrm{a}=\text { tebal lapisan lindung }
\end{aligned}
$$

(diandaikan $1.00 \mathrm{~m}$ )

$$
\mathrm{h}_{\mathrm{s}}=\text { tekanan air pada titik } \mathrm{M}=
$$

Jadi :

$$
S_{f}=\frac{3.10\left(1+\frac{1.00}{3.10}\right)}{1.87}=2.19>2.00 \rightarrow \text { OK! }
$$

Tabel 5 Harga Angka Rembesan Land $\left(\mathrm{C}_{\mathrm{w}}\right)$ sudah dijelaskan sebelumnya. Selanjutnya hasil perhitungan masing-masing alternatif tersebut diberikan pada Tabel 4. berikut.

\begin{tabular}{|l|c|}
\hline Pasir sangat halus atau lanau & 8.5 \\
\hline Pasir halus & 7.0 \\
\hline Pasir sedang & 6.0 \\
\hline Pasir kasar & 5.0 \\
\hline Kerikil halus & 4.0 \\
\hline Kerikil sedang & 3.5 \\
\hline Kerikil kasar termasuk berangkal & 3.0 \\
\hline Bongkah dengan sedikit berangkal dan kerikil & 2.5 \\
\hline Lempung lunak & 3.0 \\
\hline Lempung sedang & 2.0 \\
\hline Lempung keras & 1.8 \\
\hline Lempung sangat keras & 1.6 \\
\hline
\end{tabular}

\section{Perhitungan Stabilitas Tubuh Bendung}

Dalam peninjauan stabilitas bendung dihitung dalam keadaan kritis, yaitu waktu banjir yang bersamaan dengan gempa dan juga waktu kondisi air normal yang bersamaan dengan gempa.

Gaya-gaya yang bekerja pada tubuh bendung adalah :

$=2.00 \bullet$ Berat Sendiri Dendung $\quad(\mathrm{G})$

- Gaya Gempa

( $\mathrm{K}$ )

- Gaya Hidrostatis

( W )

(4.97 Tekanan Lumpur

( P ) $\rightarrow$

dalam hal ini

\section{pasir/kerikil}

- Gaya Uplift Pressure

Syarat yang harus dipenuhi untuk stabilitas bendung agar konstruksi aman dan stabil adalah :

1. Terhadap guling 
2. Terhadap geser

3. Terhadap eksentrisitas

Data-data tanah di sekitar lokasi sesuai dengan data yang ada :

- Berat Isi Tanah $\mathrm{t} / \mathrm{m}^{3}$

- Kohesi Tanah
- $\quad$ Sudut Geser Tanah

- Daya Dukung Tanah $\mathrm{t} / \mathrm{m}^{2}$ $\phi=$

$31.785^{\circ}$

$\mathrm{q}_{\mathrm{t}}=200$

Secara lebih jelas perhitungannya dilakukan dengan cara tabelaris.

\section{Gaya-gaya Akibat Berat Sendiri (Konstruksi)}

Gaya-gaya berat sendiri adalah gaya yang ditimbulkan oleh berat jenis dari konstruksi tersebut. Dalam konstruksi bangunan bendung dari pasangan batu kali diambil $\gamma_{\text {pas }}=2.30 \mathrm{t} / \mathrm{m}^{3}$.

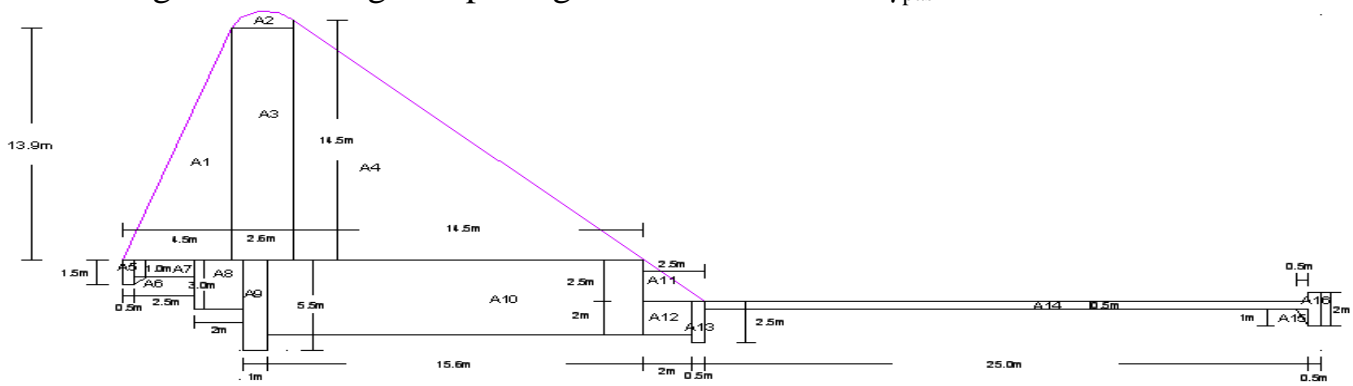

Tabel 5. Perhitungan Berat Sendiri Tubuh Mercu Embung

\begin{tabular}{|c|c|c|c|c|c|c|c|c|}
\hline \multirow[t]{2}{*}{ Gaya } & \multirow{2}{*}{$\begin{array}{r}\mathbf{H} \\
(\mathbf{m}) \\
\end{array}$} & \multirow{2}{*}{$\begin{array}{c}\mathbf{B} \\
(\mathbf{m}) \\
\end{array}$} & \multirow[t]{2}{*}{ Luas Bagian } & \multirow{2}{*}{$\begin{array}{c}\text { F } \\
\text { m2 }\end{array}$} & \multicolumn{2}{|c|}{$\begin{array}{c}\begin{array}{c}\text { Jarak titik } \\
\text { berat } \\
\text { (m) }\end{array} \\
\end{array}$} & \multicolumn{2}{|c|}{$\begin{array}{c}\text { Statis momen } \\
(\mathrm{m} 3)\end{array}$} \\
\hline & & & & & $\mathbf{y}$ & $\bar{x}$ & $\mathbf{S x}$ & Sy \\
\hline $\mathrm{A} 1$ & 13,9 & 4,5 & $1 / 2 \times 4.5 \times 13.9$ & 31,275 & 10,1 & 46,5 & 315,8775 & 1454,288 \\
\hline A 2 & & & & 2,12 & 19,8 & 43,6 & 41,976 & 92,432 \\
\hline A3 & 13,9 & 2,6 & $2.6 \times 13.9$ & 36,14 & 12,5 & 43,8 & 451,75 & 1582,932 \\
\hline A4 & 14,5 & 14,5 & $1 / 2 \times 14.5 \times 14.5$ & 105,125 & 10,3 & 37,6 & 1082,788 & 3952,7 \\
\hline A5 & 1,5 & 0,5 & $1.5 \times 0.5$ & 0,75 & 4,8 & 49,3 & 3,6 & 36,975 \\
\hline A6 & 0,5 & 0,5 & $0.5 \times 0.5 \times 0.5$ & 0,125 & 4,3 & 48,9 & 0,5375 & 6,1125 \\
\hline A7 & 1 & 2,5 & $1 \times 2.5$ & 2,5 & 5 & 48 & 12,5 & 120 \\
\hline A8 & 3 & 2 & $2 \times 3$ & 6 & 4 & 45,6 & 24 & 273,6 \\
\hline A9 & 5,5 & 1 & $5.5 \times 1$ & 5,5 & 2,8 & 44,1 & 15,4 & 242,55 \\
\hline A10 & 4,5 & 15,6 & $15.6 \times 4.5$ & 70,2 & 3,3 & 34,8 & 231,66 & 2442,96 \\
\hline A11 & 2,5 & 2,5 & $0.5 \times 2.5 \times 2.5$ & 3,125 & 3,8 & 27,2 & 11,875 & 85 \\
\hline A12 & 2 & 2 & $2 \times 2$ & 4 & 2 & 27 & 8 & 108 \\
\hline A13 & 2,5 & 0,5 & $0.5 \times 0.5 \times 2.5$ & 0,625 & 1,8 & 25,8 & 1,125 & 16,125 \\
\hline A14 & 0,5 & 25 & $0.5 \times 25$ & 12,5 & 2,7 & 13,2 & 33,75 & 165 \\
\hline A15 & 0,5 & 1 & $0.5 \times 1 \times 0.5$ & 0,25 & 2,2 & 0,7 & 0,55 & 0,175 \\
\hline A16 & 2 & 0,5 & $0.5 \times 2$ & 1 & 2,5 & 0,25 & 2,5 & 0,25 \\
\hline \multicolumn{4}{|c|}{ JUMLAH } & 281,235 & & & 2237,889 & 10579,1 \\
\hline
\end{tabular}

Berat Sendiri Tubuh Bendung $(\mathrm{G})$

$\mathrm{x} \gamma_{\mathrm{pas}}$

$.235 \mathrm{~m}^{2} \times 2.3 \mathrm{t} / \mathrm{m}^{3}$

$.84 \mathrm{t} / \mathrm{m}$

Jarak titik berat dari garis $\mathrm{X}$ :
$\bar{\Sigma} \mathrm{F} \quad y=\frac{\Sigma S y}{\Sigma F}=\frac{10579.1 \mathrm{~m}^{3}}{281.235 \mathrm{~m}^{2}}=37.61 \mathrm{~m}$

$=\quad$ Jarak titik berat dari garis $\mathrm{Y}$ :

281

$=$

646
$x=\frac{\Sigma S x}{\Sigma F}=\frac{2237.889 \mathrm{~m}^{3}}{281.235 \mathrm{~m}^{2}}=7.957 \mathrm{~m}$

\section{Gaya-gaya Akibat Gaya Gempa}

Gaya gempa $(\mathrm{K})=\mathrm{E} \times \mathrm{G}$ 
Dengan: $E=$ Koefisien gempa

$\mathrm{G}=$ Berat sendiri tubuh

bendung

Untuk mengetahui koefisien gempa, digunakan persamaan :

$$
\begin{aligned}
a_{d} & =n\left(\begin{array}{lll}
a_{c} & x & z
\end{array}\right)^{m} \\
E & =\frac{a_{d}}{g}
\end{aligned}
$$

Dengan: $a_{d} \quad=$ percepatan gempa rencana $\left(\mathrm{cm} / \mathrm{dt}^{2}\right)$

$$
\begin{array}{ll}
\mathrm{n}, \mathrm{m} & =\text { koefisien jenis tanah } \\
\mathrm{a}_{\mathrm{c}} & =\text { percepatan gempa }
\end{array}
$$

dasar $\left(\mathrm{cm} / \mathrm{dt}^{2}\right)$

$$
\begin{array}{rll}
\mathrm{E} & =\text { koefisien gempa } \\
\mathrm{z} & =\text { faktor yang }
\end{array}
$$

tergantung letak geografis

$\left(\mathrm{cm} / \mathrm{dt}^{2}\right)$

$$
\mathrm{g} \quad=\text { percepatan grafitasi }
$$

Pada pembangunan bendung ini digunakan :

$\begin{array}{llll}\mathrm{n}= & 2.76 & \text { untuk } & \text { jenis } \\ \text { tanah berbatu } & & & \\ \mathrm{m}= & 0.71 & \text { untuk } & \text { jenis } \\ \text { tanah berbatu } & & & \\ \mathrm{a}_{\mathrm{c}}= & 85 \mathrm{~m} / \mathrm{dt}^{2} & \text { untuk periode }\end{array}$

ulang 20 tahun

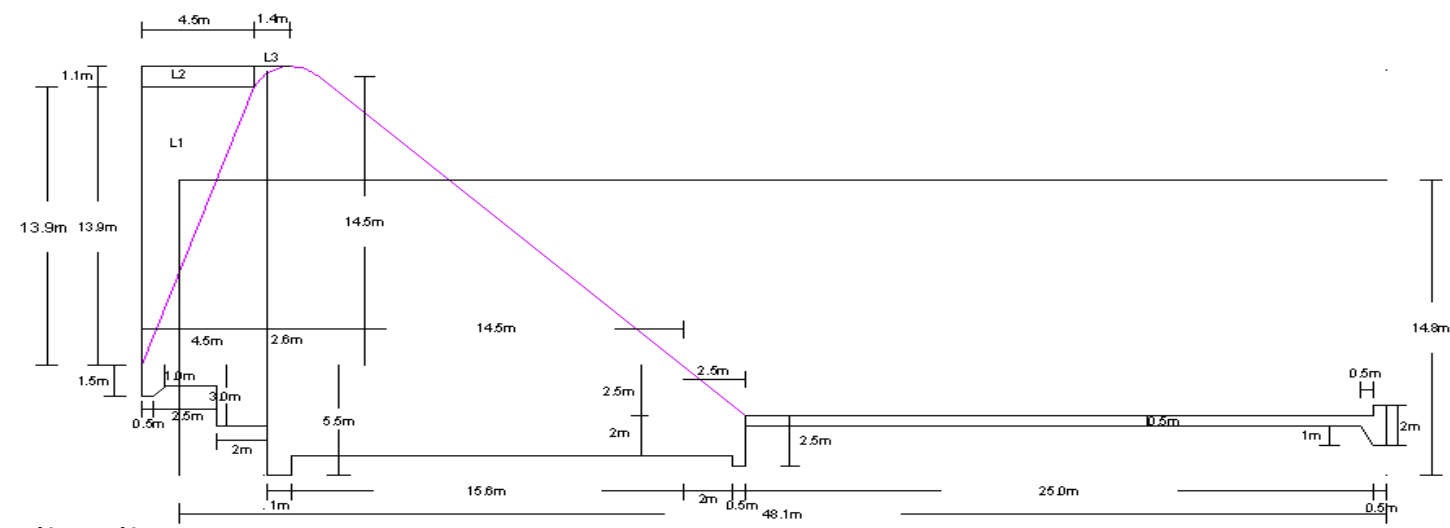

$$
\mathrm{z}=
$$

untuk zone
Maka :

$$
\begin{aligned}
a_{d} & =n\left(a_{c} \times z\right)^{m} \\
& =2.76(85 \times 1.56)^{0.71} \\
& =88.698 \mathrm{~m} / d t^{2} \\
E & =\frac{a_{d}}{g} \\
& =\frac{88.698}{981} \\
& =0.090
\end{aligned}
$$

Jadi gaya gempa $(\mathrm{K})$

$$
\begin{aligned}
& =\mathrm{E} \times \mathrm{G} \\
& =0.090 \times 646.84 \\
& =58.215 \mathrm{t} / \mathrm{m}
\end{aligned}
$$

$\mathrm{t} / \mathrm{m}$

Gaya-gaya Akibat Tekanan Lumpur (Pasir/Kerikil)

Gaya-gaya akibat tekanan lumpur dihitung dengan menganggap lumpur tertahan setinggi mercu dengan sudut geser dalam $(\phi) 31.785^{\circ}$ dan $\gamma_{t}=1.3 \mathrm{t} / \mathrm{m}^{3}$.

$$
\begin{aligned}
\gamma_{\mathrm{s}} & =\gamma_{\mathrm{t}}-\gamma_{\mathrm{w}} \\
& =1.30-1.00 \\
& =0.30 \mathrm{t} / \mathrm{m}^{3}
\end{aligned}
$$$$
P=1 / 2 \times \gamma_{s} \times h^{2} \times \frac{1-\sin \phi}{1+\sin \phi}
$$

Jarak garis kerja gaya terhadap $\mathrm{X}$ adalah :

$$
Y=\frac{\Sigma M_{y}}{\Sigma P}=\frac{0.274}{0.058}=4.724 \mathrm{~m}
$$


Vol. 3 No.2 Juni 2020

http://jurnal.umsb.ac.id/index.php/RANGTEKNIKJOURNAL

\section{Gaya-gaya Hidrostatis}

Gaya hidrostatis dihitung pada keadaan air normal dan air banjir dengan berat jenis air $\gamma_{\mathrm{w}}=1 \mathrm{t} / \mathrm{m}^{3}$.

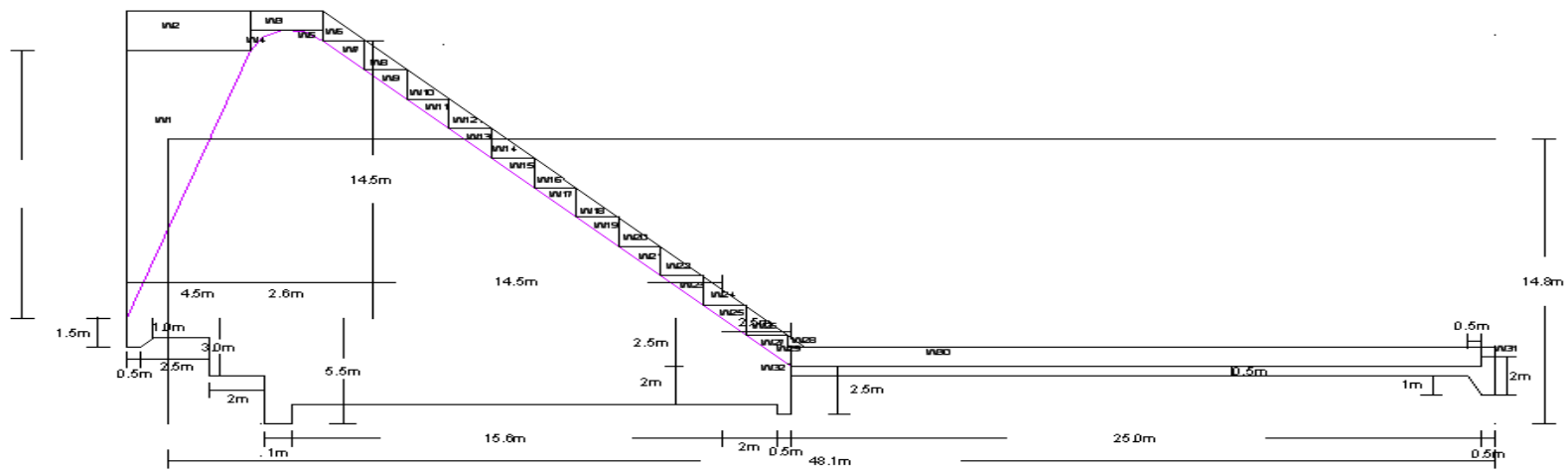

Tabel 6. Perhitungan Gaya-Gaya Pada Tubuh Mercu Embung

\begin{tabular}{|c|c|c|c|c|c|c|c|c|}
\hline \multirow[t]{2}{*}{ Gaya } & \multirow{2}{*}{$\begin{array}{r}\mathbf{H} \\
(\mathbf{m})\end{array}$} & \multirow{2}{*}{$\begin{array}{r}\text { B } \\
(\mathbf{m})\end{array}$} & \multirow[t]{2}{*}{ Luas Bagian } & \multirow{2}{*}{$\begin{array}{c}\text { F } \\
\text { m2 }\end{array}$} & \multicolumn{2}{|c|}{$\begin{array}{c}\text { Jarak titik } \\
\text { berat } \\
\text { (m) }\end{array}$} & \multicolumn{2}{|c|}{$\begin{array}{c}\text { Statis momen } \\
(\mathrm{m} 3)\end{array}$} \\
\hline & & & & & $\mathbf{y}$ & $\mathbf{x}$ & $\mathbf{S x}$ & Sy \\
\hline W1 & 13.9 & 4.5 & $1 / 2 \times 4.5 \times 13.9$ & 31.275 & & 48.1 & & 1504.328 \\
\hline W2 & 2.1 & 4.5 & $2.1 \times 4.5$ & 2.12 & & 47.3 & & 100.276 \\
\hline W3 & 2.1 & 2.6 & $\begin{array}{l}2.6 \times 2.1 \\
1 / 2 \times 14.5 \times\end{array}$ & 5.46 & 21 & & 114.66 & \\
\hline W4 & 14.5 & 14.5 & 14.5 & 105.125 & 20.3 & & 2134.038 & \\
\hline W5 & 1.5 & 0.5 & $1.5 \times 0.5$ & 0.75 & 20.3 & & 15.225 & \\
\hline W6 & 1.5 & 1.5 & $0.5 \times 1.5 \times 1.5$ & 1.125 & 20.5 & & 23.0625 & \\
\hline W7 & 1.5 & 1.5 & $0.5 \times 1.5 \times 1.5$ & 1.125 & 19.5 & & 21.9375 & \\
\hline W8 & 1.5 & 1.5 & $0.5 \times 1.5 \times 1.5$ & 1.125 & 18.9 & & 21.2625 & \\
\hline W9 & 1.5 & 1.5 & $0.5 \times 1.5 \times 1.5$ & 1.125 & 18 & & 20.25 & \\
\hline W10 & 1.5 & 1.5 & $0.5 \times 1.5 \times 1.5$ & 1.125 & 17.4 & & 19.575 & \\
\hline W11 & 1.5 & 1.5 & $0.5 \times 1.5 \times 1.5$ & 1.125 & 16.4 & & 18.45 & \\
\hline W12 & 1.5 & 1.5 & $0.5 \times 1.5 \times 1.5$ & 1.125 & 15.9 & & 17.8875 & \\
\hline W13 & 1.5 & 1.5 & $0.5 \times 1.5 \times 1.5$ & 1.125 & 13.4 & & 15.075 & \\
\hline W14 & 1.5 & 1.5 & $0.5 \times 1.5 \times 1.5$ & 1.125 & 14.3 & & 16.0875 & \\
\hline W15 & 1.5 & 1.5 & $0.5 \times 1.5 \times 1.5$ & 1.125 & 13.3 & & 14.9625 & \\
\hline W16 & 1.5 & 1.5 & $0.5 \times 1.5 \times 1.5$ & 1.125 & 12.8 & & 14.4 & \\
\hline W17 & 1.5 & 1.5 & $0.5 \times 1.5 \times 1.5$ & 1.125 & 11.8 & & 13.275 & \\
\hline W18 & 1.5 & 1.5 & $0.5 \times 1.5 \times 1.5$ & 1.125 & 11.3 & & 12.7125 & \\
\hline W19 & 1.5 & 1.5 & $0.5 \times 1.5 \times 1.5$ & 1.125 & 10.3 & & 11.5875 & \\
\hline W20 & 1.5 & 1.5 & $0.5 \times 1.5 \times 1.5$ & 1.125 & 9.7 & & 10.9125 & \\
\hline W21 & 1.5 & 1.5 & $0.5 \times 1.5 \times 1.5$ & 1.125 & 8.7 & & 9.7875 & \\
\hline W22 & 1.5 & 1.5 & $0.5 \times 1.5 \times 1.5$ & 1.125 & 8.2 & & 9.225 & \\
\hline W23 & 1.5 & 1.5 & $0.5 \times 1.5 \times 1.5$ & 1.125 & 7.2 & & 8.1 & \\
\hline W24 & 1.5 & 1.5 & $0.5 \times 1.5 \times 1.5$ & 1.125 & 6.7 & & 7.5375 & \\
\hline W25 & 1.5 & 1.5 & $0.5 \times 1.5 \times 1.5$ & 1.125 & 5.7 & & 6.4125 & \\
\hline W26 & 1.5 & 1.5 & $0.5 \times 1.5 \times 1.5$ & 1.125 & 5.1 & & 5.7375 & \\
\hline W27 & 1.5 & 1.5 & $0.5 \times 1.5 \times 1.5$ & 1.125 & 4.2 & & 4.725 & \\
\hline W28 & 0.6 & 0.6 & $0.5 \times 0.6 \times 0.6$ & 0.18 & 4.2 & & 0.756 & \\
\hline W29 & 0.91 & 0.09 & $0.5 \times 0.6 \times 0.6$ & 0.04095 & 3.5 & & 0.143325 & \\
\hline W30 & 1 & 25 & $0.5 \times 0.1 \times 1.9$ & 25 & 3.5 & & 87.5 & \\
\hline W31 & 0.5 & 0.5 & $1 \times 25$ & 0.25 & 3.7 & & 0.925 & \\
\hline W32 & 0.09 & 0.09 & $1 \times 25$ & 0.00405 & 3.1 & & 0.012555 & \\
\hline \multicolumn{3}{|c|}{ Jumlah } & $\sum \mathbf{W v}$ & 161.56 & & $\sum \mathbf{M v}$ & 2656.222 & \\
\hline
\end{tabular}


\begin{tabular}{l}
\hline$\sum$ Wh \\
$\begin{array}{l}\text { Jarak garis kerja gaya vertikal terhadap } \mathrm{Y} \\
\text { adalah : }\end{array}$ \\
$X=\frac{\Sigma M_{V}}{\Sigma W_{V}}=\frac{2656.222}{161.56}=16.44 \mathrm{~m}$
\end{tabular}

Jarak garis kerja gaya horizontal terhadap $\mathrm{X}$ adalah :

$$
Y=\frac{\Sigma M_{H}}{\Sigma W_{H}}=\frac{1604.604}{33.395}=48.04 \mathrm{~m}
$$

\section{Gaya Uplift Pressure}

Uplift pressure yaitu tekanan ke atas yang diakibatkan oleh tekanan air terhadap bidang bawah bendung. Besarnya uplift pressure dihitung dengan menentukan besarnya tekanan pada tiap-tiap titik sudut dan setelah itu dapat ditentukan besarnya gaya yang bekerja pada tiap-tiap bidang. Besarnya uplift pressure dianggap bekerja antara $67 \%$ - $100 \%$, dalam hal ini uplift pressure dihitung bekerja $70 \%$.

Rumus yang digunakan :

$$
U_{x}=\left[H_{x}-\frac{L_{x}}{L_{t}} \times \Delta H\right] \times \gamma_{w}
$$

Dengan: $U_{\mathrm{x}}=$ uplift pressure pada titik $X\left(\mathrm{~kg} / \mathrm{m}^{2}\right)$

$$
\mathrm{H}_{\mathrm{x}}=\text { selisih tinggi muka air }
$$

\subsection{5}

sampai titik X (m)

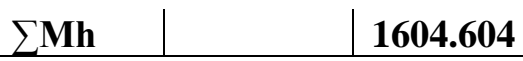

1604.604

$\mathrm{L}_{\mathrm{t}}=$ panjang creepline total (m)

(m)

$$
\Delta \mathrm{H}=\text { selesih tinggi tekanan }
$$

Panjang creepline ditentukan menurut teori Bligh. Panjang creepline sebanding dengan besarnya perbedaan tekanan dijalur pengaliran yang dinyatakan dengan rumus :

$$
\Delta H=\frac{L}{C}
$$

Dengan: $\Delta \mathrm{H}=$ perbedaan tekanan $(\mathrm{m})$

$$
\mathrm{L}=\text { panjang creepline }
$$

minimum yang dibutuhkan $(\mathrm{m})$

$$
\mathrm{C}=\text { creep ratio }
$$

Untuk konstruksi aman terhadap tekanan air, maka :

$L \geq \Delta H \cdot C$

Pada bendung ini jenis tanah pada dasar bendung adalah berupa kerikil, batu-batu kecil dan besar, maka diperkirakan creep ratio (C) untuk Bligh adalah 6 (enam).

$\Delta \mathrm{H}$ pada saat air normal $\quad=15 \mathrm{~m}$ di hulu bendung dengan titik $\mathrm{X}(\mathrm{m})$

\begin{tabular}{|c|c|c|c|c|}
\hline Titik & Elevasi $(\boldsymbol{E l x})$ & $\boldsymbol{H} \boldsymbol{x}=\mathbf{2 0 . 5}-(\boldsymbol{E l} \boldsymbol{x})$ & $\boldsymbol{L x}$ & $\boldsymbol{U} \boldsymbol{x}$ \\
\hline A & 16 & 4.5 & 10 & 2.307 \\
\hline B & 16 & 4.5 & 10.5 & 2.197 \\
\hline C & 16.5 & 4 & 11.2 & 1.544 \\
\hline D & 16.5 & 4 & 13.2 & 1.105 \\
\hline E & 14.5 & 6 & 15.2 & 2.667 \\
\hline F & 14.5 & 6 & 17.2 & 2.228 \\
\hline G & 12.5 & 8 & 19.7 & 3.680 \\
\hline H & 12.5 & 8 & 20.7 & 3.461 \\
\hline I & 13.5 & 7 & 21.7 & 2.241 \\
\hline J & 13.5 & 7 & 39.3 & $(1.618)$ \\
\hline K & 14 & 6.5 & 39.8 & $(2.228)$ \\
\hline L & 14 & 6.5 & 40.3 & $(2.338)$ \\
\hline M & 16 & 4.5 & 42.3 & $(4.776)$ \\
\hline N & 16 & 4.5 & 66.8 & $(10.149)$ \\
\hline O & 15.5 & 5 & 67.9 & $(9.890)$ \\
\hline P & 15.5 & 5 & 68.4 & $(10.000)$ \\
\hline
\end{tabular}


Jarak garis kerja vertikal terhadap bidang $\mathrm{Y}$ adalah :

$$
X=\frac{M_{V}}{V_{X}}=\frac{4,639.258}{232.445}=19.958 \mathrm{~m}
$$

Jarak garis kerja horizontal terhadap bidang $\mathrm{X}$ adalah :

$$
Y=\frac{M_{H}}{V_{Y}}=\frac{34.762}{22.352}=1.555 \mathrm{~m}
$$

\begin{tabular}{|c|c|c|l|l|l|c|}
\hline \multirow{2}{*}{ Gaya } & \multicolumn{2}{|c|}{ Besar Gaya $(\mathbf{t} / \mathbf{m})$} & \multicolumn{2}{c|}{ Jarak garis kerja gaya } & \multicolumn{2}{c|}{ Momen $(\mathbf{t} / \mathbf{m} / \mathbf{m})$} \\
\cline { 2 - 7 } & $\boldsymbol{V}$ & $\boldsymbol{H}$ & $\boldsymbol{Y}$ & $\boldsymbol{X}$ & $\boldsymbol{X}$ & $\boldsymbol{Y}$ \\
\hline $\mathrm{G}$ & 646.8405 & & 7.957361 & & 5147.144 & \\
\hline $\mathrm{K}$ & & 58.215 & & 37.6165804 & & 2189.849 \\
\hline $\mathrm{W}$ & 161.56 & 33.395 & 16.44109 & 48.049214 & 2656.222 & 1604.604 \\
\hline $\mathrm{P}$ & & 0.020909 & & 4.76 & & 0.099525 \\
\hline $\mathrm{U}$ & 232.4446 & 22.35166 & & & 4639.258 & 34.76171 \\
\hline & 1040.845 & 113.9826 & & & 12442.62 & 3829.314 \\
\hline
\end{tabular}

Garis kerja vertikal terhadap Y adalah :

$$
X=\frac{12442.62}{1040.845}=11.954 \mathrm{~m}
$$

Garis kerja horizontal terhadap X adalah :

$$
Y=\frac{3829.314}{113.982}=33.595 \mathrm{~m}
$$

\section{a. Kontrol terhadap guling}

Momen guling $(\mathrm{Mg})$

$$
\begin{aligned}
& =\mathrm{Y} \times \sum \mathrm{H} \\
& =33.595 \mathrm{x}
\end{aligned}
$$

113.982

$$
=750.917
$$

tm

$$
\text { Momem tahanan }(\mathrm{Mt}) \quad=\quad \mathrm{X} \times \sum \mathrm{V}
$$$$
=11.954 \mathrm{x}
$$

1040.845

$$
=2778.723
$$

tm

Faktor keamanan terhadap guling $\left(S_{f}\right)=\frac{M_{t}}{M_{g}}>2$

$$
S_{f}=\frac{2778.723}{750.917}=3.7 \rightarrow 3.7>2
$$

$\therefore$ Struktur aman terhadap guling

\section{b. Kontrol terhadap geser}

Faktor keamanan terhadap geser $\left(S_{g}\right)=\frac{\Sigma V \times f}{\Sigma H}>1.5$

$$
S_{g}=\frac{1040.845 \times \tan 31}{113.982}=6.239 \rightarrow 6.239>1.5
$$

$\therefore \quad$ Struktur aman terhadap geser c. Kontrol terhadap eksentrisitas

$$
e=\frac{B}{2}-\frac{\left(\Sigma M_{V}-\Sigma M_{h}\right)}{\Sigma V} \leq 1 / 6 B
$$

Dalam disain ini :

$\mathrm{B} \quad=45.5 \mathrm{~m}$

$\sum \mathrm{M}_{\mathrm{v}}=12442.62 \mathrm{tm} / \mathrm{m}$

$\sum \mathrm{M}_{\mathrm{h}}=3829.314 \mathrm{tm} / \mathrm{m}$

$\sum \mathrm{V}=1040.845 \mathrm{t} / \mathrm{m}$

$$
\begin{aligned}
e & =\frac{45.5}{2}-\frac{(12442.62-3829.314)}{1040.845} \leq 1 / 645.5 \\
& =14.47 \mathrm{~m}>7.58 \mathrm{~m}
\end{aligned}
$$

$\therefore \quad$ Struktur tidak aman terhadap eksentrisitas

d. Kontrol terhadap tegangan tanah

Daya dukung tanah dalam disain ini adalah $200 \mathrm{t} / \mathrm{m}^{2}$. Tegangan tanah yang terjadi di bawah pondasi adalah :

$$
\begin{aligned}
& \sigma_{12}=\frac{\Sigma V}{A}\left[1 \pm \frac{6 e}{B}\right] \\
& =\frac{1040.845}{45.5 \times 1.00}\left[1 \pm \frac{6 \times 7.58}{45.5}\right] \\
& \left.\begin{array}{l}
\sigma_{1}=66.539 \mathrm{t} / \mathrm{m}^{2} \\
\sigma_{2}=-20.778 \mathrm{t} / \mathrm{m}^{2}
\end{array}\right\} \sigma_{1} \text { dan } \sigma_{2} \text { kecil dari da } \\
& \therefore \quad \text { Struktur aman terhadap tegangan } \\
& \text { tanah. }
\end{aligned}
$$




\section{PENUTUP}

Berdasarkan analisis dan pembahasan pada tulisan ini dapat diambil Simpulan dan saran:

\section{Simpulan}

1. Dalam pekerjaan Detail Desain Embung Danau Kering Kota Padang, antara lain dengan melaksanakan survey topografi, survey hidrologi dan penyelidikan geologi dan mekanika tanah dilanjutkan dengan kegiatan desain bangunan embung dan kelengkapannya.

2. Dari hasil analisa desain data primer dan data sekunder dan perhitungan struktur dan pemilihan tipe, maka kesimpulan dari pekerjaan perencanaan embung ini antara lain :

Tipe konstruksi bendungan :Bendungan Beton dengan Penyangga (concrete buttress dams)

Tinggi mercu bendungan:15 meter

Tinggi bendungan:18 meter

Lebar mercu:50 meter

Panjang bendungan:154 meter

Luas genangan: 16.848 meter persegi

Volume genangan air: 894.770 meter kubik

\section{Saran}

1. Penulis yakin masih ada kekurangankekurangan untuk itu kami menerima segala kritikan dan usulan serta saran yang membangun demi terciptanya suatu hasil yang terbaik dan yang nantinya akan bermanfaat bagi Penulis sendiri dan serta pembaca laporan ini pada umumnya.

2. Sebagai penutup Penulis mengucapkan terimakasih kepada Instansi terkait dan semua pihak yang tidak dapat kami sebutkan satu persatu yang telah membantu dalam penyelesaian Penulisan "Detail Desain Embung Danau Kering Kota Padang" ini.

\section{DAFTAR PUSTAKA}

1. Chow, Ven Te. 1992. Hidrolika Saluran Terbuka (Open Channel Hydraulics). Jakarta : Erlangga.

2. Departemen Pekerjaan Umum. 2010. Standar Perencanaan Irigasi KP-01. Direktorat Jenderal Pengairan. Jakarta : Departemen Pekerjaan Umum.

3. Departemen Pekerjaan Umum. 2010. Standar Perencanaan Irigasi KP-02.
Direktorat Jenderal Pengairan. Jakarta : Departemen Pekerjaan Umum.

4. Harto, Sri Br. 1993. Analisis Hidrologi. Jakarta : Gramedia Pustaka Utama.

5. Soedibyo, Ir. 1993. Teknik Bendungan. Jakarta : Pradnya Paramida.

6. Sosrodarsono, Suyono. 1994. Perbaikan dan Pengaturan Sungai. Jakarta : Pradnya Paramita. Sudjarwadi. 1979. Pengantar Teknik Irigasi. Yokyakarta : Universitas Gajah Mada.

7. Suripin. 2003. Sistem Drainase Perkotaan yang Berkelanjutan. Yogyakarta : Andi.

8. Triatmodjo, Bambang. 2008. Hidrologi Terapan. Yogyakarta : Beta Offset. 